\title{
EL LENGUAJE BÍBLICO EN \\ LA LÍRICA AMERICANA
}

THE BIBLE LANGUAGE IN

THE AMERICAN LYRIC

Arquivo recebido em

12 de maio de 2014

e aprovado em

20 de junho de 2014

V. 4 - N. $7-2014$

* Doctor en Lingüística por la universidad de Madrid, y Licenciado en Educación por la Universidad Católica Madre y Maestra, donde es profesor. Ha publicado numerosos ensayos y estudios de lingüística y literatura en la prensa nacional, y se le reconoce como el iniciador de una nueva metodología critica en nuestro país y ampara sus análisis en datos aportados por la ciencia lingüística y afines. Ha publicado lo popular y lo culto en la poesía dominicana (1977), Juan Bosch: un texto, un análisis y una entrevista (1979), Ensayos Críticos

(1982), La imaginación Insular (1984).

El doctor Rosario Candelier, además de la docencia, escribe y publica sus estudios y ensayos; asesora revistas culturales; orienta grupos literarios en formación; proyecta coloquios y encuentros literarios, dicta y organiza charlas y conferencias; asiste a seminarios y forma parte de jurados en certámenes literarios. Es miembro de número de la Academia Dominicana de la Lengua y miembro correspondiente de la Real Academia Española. Forma parte del "Grupo de Escritores del Cibao" y del "Comité de Intelectuales Dominicanos".

En el 2008 fue galardonado con el Premio Nacional de Literatura.

\section{Bruno Rosario Candelier*}

Ay Señor

que atizas tu Sol desde tan lejos

para que yo tenga el calor

sin el que muero.

(Freddy Bretón Martínez)

A Cecilia Avenatti de Palumbo, Amanuense del sentido de lo eterno.

\section{Resumen}

La huella de la Biblia en su expresión intelectual y estética se manifiesta en la creación de poesía y ficción. La poesía religiosa y mística, así como el empleo del lenguaje bíblico a través de la recreación de personajes, temas o motivos inspirados en el texto sagrado, constituyen un tributo de exaltación al Libro sagrado y una veta creadora de la literatura inspirada en esa obra paradigmática de nuestra cultura. El lenguaje bíblico que encauza enseñanzas profundas y verdades reveladas mediante diversas figuras literarias, ha sido un fecundo medio de creación. Además de la intuición y la inspiración, en el lenguaje poético fluyen las señales de la revelación, que sintetizan la percepción de la conciencia, la 
vertiente metafísica de lo existente y los efluvios de la Trascendencia. En su realización interviene el poder creador de la poesía, que la palabra formaliza en imágenes, mitos y conceptos. En numerosas creaciones poéticas hay reminiscencias formales, conceptuales y espirituales del Libro sagrado. Es fecunda la huella de la Biblia en la literatura, la cultura y la conciencia espiritual. La palabra que crea y eleva es crisol del sentimiento estético y de la espiritualidad. De hecho, el Evangelio contiene el principio inspirador de la literatura mística cristiana. Al enfocar el lenguaje bíblico en la creación poética, apreciamos fórmulas literarias y recursos compositivos. Hay una sabiduría y una estilística inherentes al lenguaje bíblico, que se manifiesta en un tono bíblico, una imagen bíblica y una técnica bíblica, que el arte del lenguaje formaliza en diversas formas de creación. El saber proveniente de la herencia bíblica se manifiesta en sentencias, visiones proféticas, parábolas, alegorías, paralelismos y otros recursos que han pasado al caudal de la lírica. El lenguaje bíblico encarna un formato registrado en proverbios, himnos, súplicas, metáforas y otros recursos expresivos. En el texto bíblico hallamos variadas formas literarias que han alimentado la sustancia de la creación poética, como se evidencia en las creaciones poéticas de las letras americanas. El Libro sagrado ha sido fuente de inspiración estética y fruición espiritual, como genuina expresión de la conciencia y la espiritualidad del hombre a través de la historia. Muchas de las grandes creaciones literarias, especialmente la literatura inspirada en el sentimiento religioso y místico, tienen su abrevadero en la Biblia, que comprende la más importante creación verbal sobre la historia y el destino del género humano.

Palavras-clave: poesía, lenguaje bíblico, mística, figuras literarias, inspiración.

\section{Abstract}

The footprint of the Bible in its intellectual and aesthetic expression is manifested in the creation of poetry and fiction. The religious and mystical poetry, and the use of biblical language through the recreation of characters, themes or motifs inspired by the sacred text, are a tribute to the Holy Book and a creative vein of literature inspired by this paradigmatic work of our culture. The biblical language that channel profound teachings and revealed truths through diverse literary figures, has been a fruitful means of creation. Besides intuition and inspiration, in the poetic language flowing the signals of revelation that synthesize perception of consciousness, the metaphysics slope of the existing and the effluvia of Transcendence. In its implementation intervenes the creative power of poetry that the word formalized in images, myths and concepts. In numerous poetic creations there are formal, conceptual and spiritual reminiscent of the Holy Book. It's prolific the trace of the Bible in literature, culture and spiritual awareness. The word that creates and raises is a melting pot of the aesthetic feeling and spirituality. In fact, the Gospel contains the inspiring principle of Christian mystical literature. By focusing biblical language in poetic creation, we appreciate literary formulas and compositional resources. There is a wisdom and a stylistic inherent in biblical language, which manifests itself in a biblical tone, a biblical 
image and a biblical technique that the language arts formalized in various forms of creation. Knowing from the biblical heritage is reflected in judgments, prophetic visions, parables, allegories, parallelisms and other resources that have fallen into the lyrical flow. The biblical language embodies a format registered by proverbs, hymns, prayers, metaphors and other expressive resources format. In the biblical text we find various literary forms that have fueled the substance of poetic creation, as evidenced in our continent poetic creations. The Holy Book has been a source of artistic inspiration and spiritual enjoyment, as a genuine expression of consciousness and spirituality of man through history. Many of the great literary creations, especially the literature inspired by the religious and mystical feeling, have their drinking trough in the Bible, which comprise the most important verbal creation on the history and destiny of mankind.

Key words: poetry, biblical language, mystical, literary figures, inspiration.

\section{EI lenguaje bíblico en la cultura literaria}

Los libros de la Biblia contienen las verdades reveladas de la Sagrada Escritura y, en tal virtud, constituyen una magnífica fuente literaria para apreciar el vínculo entre el hombre, la naturaleza y la divinidad. El asombro y el misterio que despiertan las manifestaciones sensoriales y suprasensibles en sus vertientes físicas y espirituales, desde la apelación inicial de los efluvios naturales hasta los motivos de inspiración y júbilo que exaltan la Creación del Mundo, forman parte de las maravillas de lo viviente asumidas como obra de Dios, que el Salmo 104 resalta: "Cuántas son tus obras, Señor, y todas las hiciste con maestría, la tierra está llena de tus criaturas. (...) Cantaré al Señor mientras viva, tañeré para mi Dios mientras exista: que le sea agradable mi poema y yo me alegraré con el Señor".

En su contacto con fenómenos y cosas, el ser humano tiene sensaciones, emociones y pasiones que los creadores asumen como fuente de poesía y ficción. Ante la contemplación de lo viviente, se despierta el sentimiento de la belleza, base de la sensibilidad estética; ante el esplendor del mundo, se despierta el sentimiento de admiración de los encantos naturales, base de la sensibilidad cósmica; y ante al asombro que 
genera el misterio de lo existente, nace el sentimiento de lo divino, base de la sensibilidad mística. Fascinados por la hermosura de la Creación, los hombres se extasían en su contemplación y, como dice el Libro de la sabiduría (13, 1-2), son vanos los hombres que ignoran la obra divina:

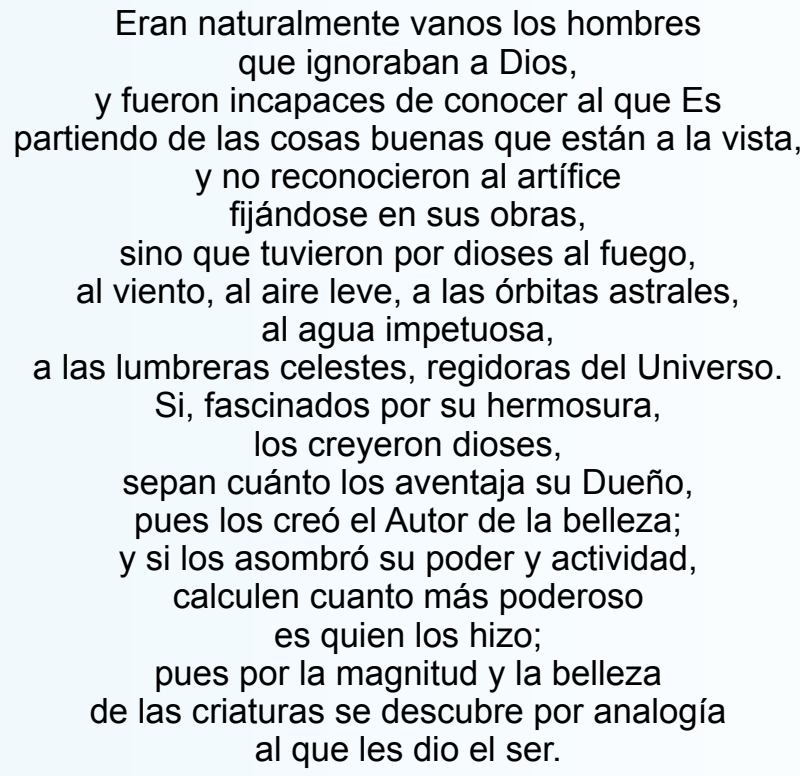

Se sabe desde antiguo que un aliento trascendente insuflaba el soplo divino a los profetas, como lo testimonia Ezequiel $(50,3)$, cuando alude al Espíritu Santo o, lo como decían los apóstoles Juan y Pablo, que la palabra es expresión de la imagen divina en la conciencia humana (Gál, 4,24 y Jn, I, 1-14). Lo divino subyacente en nuestro interior lo anuncia el Libro de la Sabiduría $(12,1)$ : "Todos llevan Tu soplo incorruptible".

La palabra sagrada de la Biblia contiene el principio inspirador de la mística cristiana. Inspirada en la doctrina de Cristo, nació la mística cristiana cuyo conocimiento místico alude a un saber secreto, misterioso y profundo, según san Pablo: "Enseñamos una sabiduría divina, misteriosa y secreta, un saber escondido por Dios antes de los siglos, para nuestra gloria..." (I Cor, 2,7). Se atribuye a Pseudo Dionisio Areopagita, uno de los antiguos pensadores cristianos, el sentido de la palabra mística, 
que definió como "el anhelo divino de la Realidad inmaterial". Al respecto escribió: "(...) verdadera comunión con la luz inmaculada y sublime de espléndida e inefable hermosura". Consignó este teólogo cristiano que los contemplativos "están llenos de una luz superior que excede todo conocimiento" porque "han logrado entrar en comunión con Dios" y, en tal virtud, participan "del conocimiento hondo de las luces divinas" (1).

Pues bien, esa "sabiduría divina y secreta" o ese "saber escondido" de que hablaba el apóstol Pablo, se corresponde con el sentido etimológico de la palabra mística. Del verbo griego $\mu \iota \epsilon \iota \nu$ [miein], 'cerrar', en alusión a 'cerrar la boca', 'guardar secreto', 'permanecer callado', se derivaron 'misterio', 'mito' y 'mística', términos emparentados lexicológica y semánticamente con el vocablo griego. La mística entraña, por tanto, un aliento misterioso, secreto y oculto, condición a la que no escapa ninguna de las tendencias contemplativas, incluyendo la cristiana, en tanto fenómeno de la espiritualidad en la que subyace la experiencia del misterio de lo divino y la fe en la trascendencia espiritual. Ya el Areopagita puntualizó: "El rayo luminoso de aquellos sacratísimos misterios ilumina directamente, y en todo su esplendor, a los hombres de Dios, porque estos se mantienen familiares a la Luz" (Ibídem).

La poesía religiosa y mística asume los efluvios metafísicos de la Trascendencia y, desde luego, el sentido de la religiosidad confesional. En sentido filosófico, todo el que experimenta un vínculo de identificación con alguna faceta del mundo o del Universo tiene una inclinación religiosa. $Y$ en sentido doctrinario, el concepto de religiosidad entraña una vinculación con un credo, una doctrina y un ritual. La palabra religión viene del latín religare ('ligar', 'vincular', 'relacionar'), lo que entraña una relación con la naturaleza de lo viviente o con una credo confesional o doctrinario.

Hay una tradición bíblica, una tradición poética y una tradición religiosa. La poesía religiosa y mística, así como la que usa el lenguaje bíblico mediante la referencia de personajes, temas o motivos inspirados 
en la Biblia, es un canto de oración o de exaltación al Creador del Mundo $y$, en tal virtud, constituye una valiosa veta creadora en la literatura inspirada en el Libro sagrado de la cultura de Occidente.

La lengua bíblica está impregnada de imágenes, que toma de la naturaleza, para encauzar verdades suprasensibles, que son verdades reveladas, verdades metafísicas o verdades de vida. Además de la intuición, en el lenguaje poético fluyen la inspiración y la revelación, que constituyen la expresión de la conciencia, la dimensión metafísica de la realidad y las emanaciones de la Trascendencia. En su realización interviene el poder creador de la poesía. En muchas creaciones poéticas hay reminiscencias de todos los textos del Libro sagrado, así como de sus personajes, temas y figuraciones literarias.

En sentido bíblico, la creación es un acto nuevo, una nueva ideación de la realidad o una nueva connotación de lo existente. Crear entraña inventar, concitar un proceso, generar una renovación del sentido. Crear es dejar que el poder de la palabra fluya, que el sentido del lenguaje actúe sobre la sensibilidad y la conciencia. El sentido bíblico de crear es abrirse al proceso de vivificación y renovación. Dejar que el amor fluya es crear. Dejar que la esperanza fructifique es crear. Dejar que la compasión actúe o que la sabiduría ilumine es crear. Y, desde luego, dejar que la palabra se active y fecunde.

La huella de la Biblia en la literatura, la cultura y en nuestra conciencia espiritual es fecunda. La palabra que crea y transforma es crisol de aliento que ahonda en la espiritualidad. Y ese influjo tiene su origen en el mensaje bíblico. El poeta español Fernando Rielo decía que el Evangelio "contiene el código de la lectura mística". Al enfocar el lenguaje bíblico, hay que conocer y valorar algunas de las fórmulas bíblicas canalizables en poesía. La sabiduría inherente al lenguaje bíblico se manifiesta en Tono bíblico (aclamación, súplica, lamentación, interrogación); imagen bíblica (metáfora, alegoría, paradigma, parábola, proverbio); y técnica bíblica (paralelismo, himno, acción de gracias, lamentos, versos dísticos 
y trísticos, estribillos).

Asimismo, podemos hablar de personajes, temas y motivos bíblicos, que se han usado como fuente de inspiración en poesía y ficción. La sabiduría inherente al contenido bíblico implica la creación de sentencias ("Yo soy la luz", "la vid verdadera"), evocación de personajes bíblicos (Urias, Ruth y otros), visiones proféticas y apocalípticas (las de Elías o san Juan, entre otros), paremias y parábolas que han pasado al caudal paremiológico del lenguaje común.

La palabra poética que asume el lenguaje bíblico encarna la sabiduría inherente en proverbios, himnos, súplicas, metáforas, alegorías y otros recursos expresivos. En la Biblia hay varias formas literarias que han nutrido la sustancia de la creación poética.

El Libro sagrado es también fuente de inspiración estética y fruición espiritual, como expresión de la conciencia y la sensibilidad humanas. Muchas de las grandes creaciones literarias, especialmente la literatura inspirada en el sentimiento religioso y místico, tienen su abrevadero en la Biblia, que comprende la más reveladora creación verbal sobre la historia, el sentido y el destino del género humano.

La expresión de imágenes y conceptos, el hallazgo de intuiciones metafísicas, así como la vertiente lírica y simbólica de las emociones entrañables y de las verdades trascendentes tiene su mejor cauce en la creación poética. En casi todos los textos canónicos de la Biblia hay poesía y en gran parte de los poetas americanos hay huellas conceptuales o literarias del influjo bíblico en su numen creador.

En las siguientes ilustraciones presentamos creaciones de los diferentes países americanos como evidencia de la huella del Libro sagrado en el cultivo de las letras.

\section{Autores y textos poéticos americanos}

George Eliot Clarke (Canadá, 1960). Poeta y dramaturgo afroca- 
nadiense y profesor de literatura de la diápora canadiense y africana en la Universidad de Toronto. En su antología Fuego en el agua, Clarke utiliza la imaginería bíblica, así como alusión al Génesis, Salmos, Proverbios y Apocalipsis para presentar escritos y temas vinculados a la historia de los negros. Se inspiró en una experiencia real cuando escribió "The emissaries", que redactó con la ironía usual de los antiguos profetas bíblicos al advertir el desprecio de algunos por el Libro sagrado:

Manzanas rojas y marrón café en los albores del añil temprano

emparejados,

formas oscuras de los patos

moviéndose en el agua, parecen extrañas rocas

o los pechos de mi hija

mientras la autopista evoca

imágenes de autos y paradas de camiones.

El letrero del motel deslumbra en color rojo sangre,

frente a una casa de los recién muertos.

El cuerpo negro de una Biblia, linchado en el árbol de una mesa, está lo más inmóvil posible.

La leería si yo fuera capaz

(si sus palabras no fuesen aves rapaces en un bombardero -cielo, oliva y gris) amantes que funcionan con monedas intercambio de lucro en tapas frías.

Penetrantes luces de lámparas de Moloch

lanzan flechas de electricidad

para expulsar a la oscuridad donde acampe

en los mercados de valores de la ciudad.

Y alteraría si hubo cambio

para alterar lo que no se ha pre-arreglado.

He perdido mucho de lo que no era nada (incluso las estrellas por encima de los lagos son la formación de espuma).

¿He dicho que los pechos de mi hija son como dos jóvenes, cisnes negros?

¿Que cada generación de vacío descansa

a mi trabajadora de esos fondos inútiles? Ir adelante por la mañana para mantener vivo

el destino humano,

la "unidad demasiada humana..." (2). 
Fray Paul Dupuis (fray Pablo de Jesús, Nueva Inglaterra, EE.UU., 1942). Poeta y monje norteamericano que cultiva la mística a la que acude como su manera predilecta de expresarse y hacer sentir su vivencia espiritual y estética, que funda en la experiencia de lo divino a cuyo través encauza sus intuiciones de la verdad, la belleza y el misterio. Dotado de la gracia contemplativa y estética, el poeta asume la mística cristiana con identificación de las tendencias espirituales orientales y, revestido de pureza lírica, aliento platónico y el poder de la teopoética con arraigo en la mística bíblica, crea una poesía para concitar en el espíritu el fuego de lo divino, como se refleja en "Elementos", para aludir a "una tierra nueva" y "un cielo nuevo", como dice el texto sagrado:

Los cielos cubren la tierra

Tú me cubres a mí tu cabeza sobre mi corazón.

Las tinieblas de tu sueño sobre mi caos primigenio.

El Espíritu de Dios mueve las aguas,

respira vida en mi boca.

Y sol en mi corazón. Mi carne deviene una tierra nueva.

Mi espíritu un cielo nuevo

y las cosas de antes

fibras del traje nupcial.

En efecto, la lírica de fray Paul Dupuis o Pablo de Jesús explora el sentido trascendente de sus símbolos poéticos y desentraña las facetas entrañables de su iluminación mística. Este poeta americano canta desde el hondón de su intimidad en busca del yo personal. La expresión del lenguaje del yo profundo, que en Norteamérica viene avalada por la ética calvinista y la estética trascendental, recoge el sentido de la divinidad inherente al individuo, concepción fincada en la convicción de que en el interior de la propia conciencia, como sostenían san Agustín de Hipona y san Juan de la Cruz, subyace el aliento sagrado que nos empata a lo divino (3).

La lírica de fray Pablo de Jesús o Paul Dupuis revela una compenetración sensorial, afectiva, imaginativa y espiritual con arraigo en la 
sacralidad y la trascendencia. Entraña una manera de ver el mundo desde una óptica sutil en la que la conciencia es fuente de reflexiones e intuiciones como base para asumir y plasmar lo que define el perfil de lo intangible. Es un intento lírico, metafísico y simbólico de descifrar el sentido sagrado de las cosas en una reflexión impregnada de misterio, emoción y belleza, como lo hace este poeta interiorista: "Porque incendiamos los puentes detrás,/ no pudimos volver a la orilla anchurosa;/ fue preciso buscar nuestro otro ser/ en la sima del alma./ El único sendero a recorrer/ lo inventamos en el trayecto./ ¿Existió alguna vez un camino tan angosto?/Me temo que fuimos sorprendidos/ atisbando al dios,/ y más todavía, de todas las voces que murmuran/ los ecos del pasado,/ nos hallaron/arrobados, en resonancia feliz,/ escuchando de la boca de toda la belleza/ la Voz irrevocable del Amigo" (“La voz").

Fray Paul hace de la lírica un medio de comprensión de lo divino para hacer sentir en el espíritu la belleza sublime, el aliento cósmico en su expresión espiritual y, sobre todo, la presencia del aliento trascendente. En su poema "Feu sans matiere", mediante un sutil ingenio de inspiración bíblica y sabiduría mística, con el lenguaje traslaticio expresa:

Dije al Señor:

-Señor, de noche sueño

que estoy pensando en ti, y de día pienso que estoy soñando en ti. ¿Cuál de las dos realidades es el sueño?

Me contestó el Señor:

-¡Despiértate, José!

Ya Herodes mandó sus tropas

para matar al niño nacido dentro de ti.

Coge al niño y a su madre

y escápate a tu Egipto interior.

Allí sabrás cuál de los dos sueños es la realidad.

Amado Nervo (México, 1870-1919). La tradición poética de inspiración religiosa tiene en el mexicano Amado Nervo a un paradigma de la creación centrada en la dimensión trascendente. Poeta modernista, creó una expresión diáfana y fluida, impregnada de un sentimiento religioso 
con fino erotismo y piadosa devoción espiritual. Autor reconocido por el fervor de su fe religiosa y la hondura de su espiritualidad mística, en algunos de sus poemas vemos el uso de la interrogación al antiguo modo del decir bíblico, según ilustra el poema "Viejo estribillo" (4) cuya lírica religiosa es un manjar en letras de la divina estirpe:

¿Quién es esa sirena de la voz tan doliente, de las carnes tan blancas, de la trenza tan bruna?

Es un rayo de luna que se baña en la fuente, es un rayo de luna...

¿Quién gritando mi nombre la morada recorre? ¿Quién me llama en las noches con tan trémulo acento?

Es un soplo de viento que solloza en la torre, es un soplo de viento...

Di, ¿quién eres, arcángel cuyas alas se abrasan en el fuego divino de la tarde, y que subes por la gloria del éter? -Son las nubes que pasan, mira bien: son las nubes...

¿Quién regó sus collares en el agua, Dios mío? Lluvia son de diamantes en azul terciopelo... -Es la imagen del cielo que palpita en el río, es la imagen del cielo...

- Oh Señor, la belleza solo es, pues, espejismo! Nada más Tú eres cierto; sé Tú mi último Dueño. ¿Dónde hallarte, en el éter, en la tierra, en mí mismo? -Un poquito de ensueño te guiará en cada abismo, un poquito de ensueño...

Gustavo González Villanueva (Guatemala, 1938). Agraciado con el don de la palabra poética y la gracia sacerdotal, tiene una intuición altamente desarrollada para atrapar los efluvios sutiles del Cosmos, que cultiva inspirado en la onda de la gracia mística. Consciente del valor poético que distingue la alta creación artística, el poeta guatemalteco y miembro correspondiente de la Academia Dominicana de la Lengua asume la vertiente interior de lo que acontece en la realidad de lo existente cuya dimensión espiritual resalta y promueve. Las sensaciones de las 
cosas concitan las tendencias intelectuales, afectivas y espirituales para captar y expresar el sentido profundo. Tiene este eminente poeta interiorista el don de capturar verdades metafísicas que expresa en formas estróficas tradicionales y modernas con las que canaliza su invención creadora: sabe plasmar, a través de anécdotas, parábolas y alegorías de la rica tradición bíblica, reveladores mensajes destinados a humanizar la visión de la vida para procurar la vertiente espiritual y trascendente a la luz del mensaje cristiano. Poeta nutrido en la veta teológica del catolicismo, curcutea el más hermoso sentido de las cosas desde la onda espiritual que el numen de lo sagrado impregna a su conciencia. Con el eco del "Cantar de cantares" este ilustre cantor oriundo de la ciudad de Antigua impregna de prosapia bíblica y caudal semítico su creación al asumir el mundo como réplica de "la viña del Señor" en la que goza con fruición el júbilo de sentir el placer del espíritu. En sus poemas revive el zumo castizo de la lírica hispana con la huella clásica del buen decir, que este moderno juglar le insufla al arte culto popularizante (5):

Con qué mano segura me escribías tus cartas;

y tu caligrafía me trazaba horizontes de ideales muy grandes.

Las nubes y los mares alineaba tu pluma que ponía, a su arbitrio, volcanes y montañas, ciudades y poblados.

Y cómo se elevaba por altas teologías de sonoras campanas,

las altas teologías de tu garbo cristiano, de la mujer esposa, de la mujer materna señora de su casa;

verdades atrevidas, misterios recorridos en idas y venidas por las calles de Antigua.

La Trinidad profunda tratabas como hija; la Encarnación vivías misterio de tu entraña:

al anuncio del ángel tu corazón saltaba como Isabel, la prima, llegada su Señora. Cómo vas a estar muerta si vivías tu vida de la vida no creada, si vivías de fe.

Si siempre sonreías, si tú te alimentabas de ese pan que es la vida más allá del desierto, que supera el maná. 
No es cierto, no es cierto.

Yo te dejé dormida...Tal vez te despertaste

y fuiste por el pan, y aun no has vuelto

porque encontraste amigas

que te cuentan sus penas, que piden tu oración.

Esperaré a la puerta a que vuelvas sonriente:

te daré la sorpresa de estas rosas que traigo

de San Juan...Si tardas en venir,

que no te importe: yo espero aquí.

Si a la amiga otra amiga

se junta, y las dos llaman otras amigas

y se ponen a hablar,

no te importe, yo espero.

$\mathrm{Si}$, yo espero a la puerta:

te entregaré tus rosas de San Juan.

Julieta Dobles (Costa Rica, 1943). Esta poeta, educadora y miembro de número de la Academia Costarricense de la Lengua cursó estudios de Ciencias Biológicas y tiene una maestría en Filología Hispánica, con especialidad en Literatura Hispanoamericana. Signataria del Movimiento Trascendentalista, tiene una obra poética inspirada en el paisaje y la vida. El vínculo espiritual que Julieta Dobles procura de la veta sensorial de lo viviente logra un cauce vinculante con la fuente genesíaca del mundo por lo cual la poeta costarricense intuye la peculiar condición de fenómenos y cosas que canaliza con la emoción de enfocar no solo el aura del paisaje, sino el alma de criaturas y elementos con una voz limpia y fresca en un acento jubiloso. En "Diciembre" (6), ausculta el genio tutelar de las cosas con aire pastoril y la evocación bíblica del pesebre que alienta la llama increada de lo Eterno:

Te nos llegas, diciembre, con tu pasito incierto de abuelo de la escarcha.

Hay un lejano don de nieves presentidas cuando el invierno nos envía del norte esos vientos puntuales y fresquísimos, inminencia de que algo estalla, jubiloso, desde los ritmos alisios del planeta, mientras Venus gobierna las tardes asombradas.

Ven, diciembre y tráenos -bocanada de verde himno de savia- 
el reino del ciprés y de su aroma.

Ven con tus aires llenos de pastoras, esas grandes estrellas escarlata que recogen el sol de todo el año y lo trasmutan en su centro amarillo y cordial.

Las mismas que recogen el himno del jardín, e inundan mesas, escaparates e ilusiones, ponen su villancico deslumbrante y humilde, bocanada ferviente de la tierra, cerca del Niñodiós,

$y$ de las ingenuas figuritas del pesebre, que pasan su frágil vida de aserrín y de sueños remontando hacia atrás el tiempo y los milagros.

Allí, el buey y la mula de madera se las arreglan para dar calor

a la hermosa familia atribulada

entre el aliento aromoso de los musgos que nos trae la montaña, y el aserrín teñido de fantasías.

Ven y ofrece también, arbolillo, arbolillo,

la vida, ritmo y celo de tus agujas breves jugosa resurrección de los inviernos,

verde, verde canción perenne del viento de la vida y sus perfectos círculos recurrentes y eternos.

Diciembre, serás siempre

la música del aire, la escarcha fantasiosa sobre el árbol que muere de plateado y brillante lleno de ajenos frutos, esferas trasparentes de pura liviandad, burbujas de la alegría primera, añoranzas humanas

de una belleza sin dolor ni sombras, de una paz extensísima, sábana igualitaria sobre el mundo, de una fraternidad que fuera música, acorde tan azul y tan alto

como el perfecto cielo de cada nochebuena.

Conny Palacios (Nicaragua, 1953). Poeta, profesora y miembro 
correspondiente de la Academia Nicaragüense de la Lengua. Concitada por el alma de los elementos y apelada por el fulgor de lo viviente, la persona lírica de estos entrañables versos revela la voz que la invita a vivir la verdad que la apela y la belleza que le inspira desde cada criatura viviente o cada efluvio trascendente. Sabe esta valiosa poeta mística del Interiorismo que los sentimientos no canalizados se enredan traumando sus entrañas, por lo cual acude a la poesía para trasvasarlos con el sentido de la creación estética y simbólica. Tiene esta agraciada poeta americana una manera dulce, emotiva y sutil de decir las cosas con la emoción pura e íntima del alma. Sus poemas concitan una alta fruición al disfrutar la emoción estética impregnada del aliento de lo sagrado, presencia vaporosa que enciende la vocación poética de esta creadora que se nutre bajo la llama de la dolencia divina. Su lírica tiene un arraigo en hondas experiencias trascendentes y su expresión estética es un canal de la sabiduría y el amor de la Energía sutil del Universo. Sus creaciones delatan el cauce de su sensibilidad empática con el lenguaje de la alegoría en una onda interior de redención y optimismo. Su honda condición sensible provoca en la persona lírica el anhelo de dejarse poseer por la vida, al tiempo que experimenta la emoción pura en sus diversas formas y texturas. En "Espejismo es la tierra prometida" (7), la poeta escribió bajo la inspiración del tema bíblico:

Levanté el ancla

y como vigía avezado

me abracé por muchas lunas

al alto mástil de mi barco,

oteando en la distancia algún sitio para desembarcar...

Inútil ha sido el ansia encabritada en el pecho...

Ineficaces mis cabellos

que no saben enredar otras melodías...

Improductivos mis dedos

que no saben tocar la canción de otras tierras...

Estéril ha sido esta sal que cubre mis llagas...

Infecundo el horizonte

que no florece en paisajes...

Inservible este cansancio,

que ya me dobla... 
Solo el grito de los cormoranes y el agua que amenaza con hundirme...

Espejismo es la Tierra Prometida.

Luis Velásquez (Honduras, 1981). Del joven poeta integrante del Interiorismo en Honduras, el sacerdote y poeta Fausto Leonardo Henríquez consignó: "Nació en San Pedro Sula el 27 de septiembre de 1981 (...). Es miembro fundador del grupo interiorista "Los Novísimos". Escribe poesía y cuento y ha ganado importantes premios regionales de poesía. Posee innegables inclinaciones intelectuales, con un gran potencial como poeta. Expresa en su creación una profunda sensibilidad, en un contexto conceptual, cimentada en la estética del movimiento interiorista" (8). En uno de sus poemas, el joven poeta sampedrano enlaza su creación a la voz del Cosmos, que su lírica recrea con devota unción mística a la luz de la llama votiva del Libro sagrado:

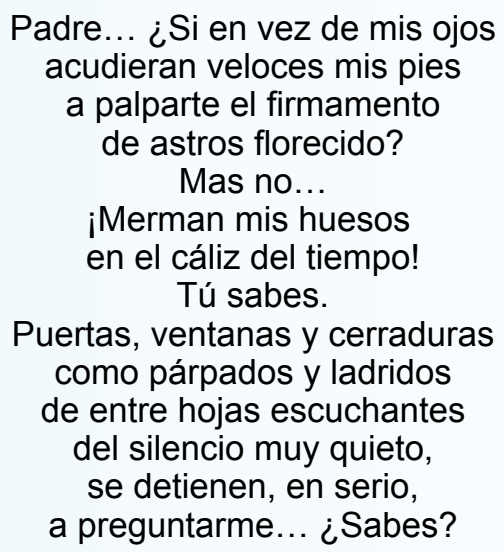

En alusión al séptimo día bíblico, Luis Velásquez imagina el "Octavo día", cuando ubica el tiempo de descanso del Creador del Mundo, según el mensaje bíblico:

(Aire, cansancio acumulado del tiempo) en la dimensión del mar un costado furtivo del aire dibuja arenas en el viento.

Es el octavo día de los días. 


\section{Mi Padre ha creado un lago \\ ancho como su voz, profundo como su tacto, donde guarda -serenándose de cosmos- sudores y lágrimas suyos: reminiscencias \\ de la faena cuando empezó... \\ a cansarse el tiempo.}

David Escobar Galindo (El Salvador, 1949). Poeta, escritor y académico, dirigió la Academia Salvadoreña de la Lengua. Este distinguido intelectual salvadoreño ha hecho de la palabra el mejor testimonio de la más alta condición espiritual del hombre. De su poemario Hombre hacia Dios, que confirma el aliento de su vocación religiosa y la fuerza de su lírica centrada en el cultivo de lo divino, tomamos el siguiente poema inspirado en el decir bíblico bajo la iluminación del sentido místico del mundo (9):

Como en los epigramas de los poetas clásicos,

Roma es el universo

en que vuelvo a sentirme ciudadano del tiempo.

Nunca visitaré una catacumba.

No soy de los primeros cristianos perseguidos.

Renuncio al privilegio de haber oído a Pedro cuando aún no era santo.

Roma, para mis ansias de velador contemporáneo, es una límpida taberna con vinos inefables. No busco a Dios en Roma.

Pero en Roma empecé a escuchar un eco.

Me paré en una esquina a ordenar las palabras que me era dable descifrar. Busqué a mi alrededor y descubrí unos ojos.

Eran los tuyos, Titi, inmensos como el alma.

Supe que en esos ojos estaba Dios mirándome.

Desde ese instante soy hombre de Dios.

José Guillermo Ros-Zanet (Panamá, 1930). Poeta, ensayista y médico, dirigió la Academia Panameña de la Lengua. Prevalido del aliento más intenso de la vida y del don de la palabra creadora, el poeta panameño reconoce el otro don que comparte con el Creador del Mundo: el 
de la creación, el más alto signo del empalme de lo divino en lo humano, llama de luz que subvierte la sombra en cuyos saltos va de lo mineral a lo vegetal y de lo vegetal a lo humano trascendido o, como dice el poeta, "al lirio de las bodas y los salmos", es decir, una manera bíblica de aludir a la fragua del amor que se hace luz en el espíritu, potenciado por el aliento estético de la expresión poética:

Dura la soledad

hasta encender los panes y los peces.

$Y$ se encienden las manos de la ofrenda.

Salen dulces aldeanas en la tarde y recogen trocitos de sal y de inocencia.

Criaturas de la luz vienen de sombras.

Llegan del territorio mineral

al pétalo del agua,

al sitio manantial de los abuelos,

al lugar infinito de los hijos,

al lirio de las bodas y los salmos, como un fulgor del tiempo.

En otro de sus poemas (10), el poeta panameño retoma los personajes bíblicos del Génesis para articular su visión del mundo inspirada en la bondad de lo viviente, que contrapone a la vil acción narrada en el primer libro de la Biblia, expresada con formas dísticas y técnicas paralelísticas, según el modelo del Libro sagrado:

Caín de los suplicios.

Y Abel enmudecido.

Las manos desatadas.

La sangre del cordero.

Salir como encendido.

Tornar iluminado.

Caín de la vigilia

y Abel el bien velado.

Caín el enterrado.

La sangre se ha encendido

de Dios y de memorias. 
Lo escrito como un muro se ha cumplido.

Unir y desunir como una espada.

Principio o fin y nunca, en una sola carne consumados.

Estirpes del prodigio.

Y asumir la pureza.

El ser. Los huesos hondos y acordados.

Los signos temporales.

Y las lilas al fondo del verano.

El justo mandamiento que nos junta

la clara ancianidad, la sombra, el desvarío.

Mortaja y claridad como la llama.

Cecilia Meireles (Brasil, 1901-1963). Esta singular poeta brasileña supo mirar el mundo con espíritu de eternidad, resaltando lo que vale, trasciende y permanece. Centrada en la veta espiritual de lo viviente, tal vez no con la marca de la sangre bíblica como la poeta brasileña percibía a su amiga y colega chilena Gabriela Mistral, sino con la huella del aliento franciscano, una manera sutil de expresar el más arraigado sentimiento cristiano hacia las criaturas y, prevalida de la visión seráfica ilustrada en la vida y la obra del Poverello de Asís, escribía con la pasión de sentir el encanto de lo viviente. Como los ascetas y los místicos, Cecilia Meireles supo asumir los tormentos y las desdichas de la existencia como sacrificio por el dolor del mundo y, como creadora, pudo amasar la sustancia de adversidades y de penas para hacer con ella la fuente de una creación con sentido trascendente, como revela en "Anunciación" (11), poema escrito con formas simbolistas, modernistas y surrealistas: 
Suena esa música de seda, débil y trémula, que apenas mece la noche y balancea en otro mar las estrellas.

Del fondo de la oscuridad nacen vagos navíos de oro, con las manos de cuerpos olvidados casi desvanecidos en el viento.

Y el viento bate las cuerdas y estremece las opacas velas, y el agua derrite un brillo fino que en sí mismo se consume.

Suena esa música de seda, entre arenas y nubes y espumas.

Los remos se detendrán en medio de la ola entre los peces suspendidos; y las cuerdas cortadas andarán por los aires danzando sin destino.

Cesará esa música de sombra que apenas indica valores de aire. Ya no existirá nuestra vida, tal vez no exista ni el polvo que fuimos.

Y la memoria de todos disolverá sus dunas desiertas, y en navíos nuevos navegarán hombres eternos.

Rufino Blanco Fombona (Venezuela, 1874-1944). Natural de Caracas, escribió desde temprana edad y compartió su vida entre el ejercicio de la política y la literatura. Ensayista, poeta y narrador, publicó numerosos libros y su poesía es una de las más representativas de las letras venezolanas. En "Corazón adentro" (12) se nota el aliento bíblico de una lírica impregnada de referencias simbólicas en las notas del paisaje y de los sentimientos del alma, escrita con la fuerza de la pasión estética:

Entré al recinto gris, donde surtía otra fontana en quejumbroso canto; ¡el canto de las lágrimas! Yo había hecho verter tan generoso llanto.

Entré al recinto gualda; siete luces, siete cruces de llama fulgecían, y los Siete Pecados se morían crucificados en las siete cruces.

Y a Psiquis alas nuevas le nacían. Rememoré las voces del Misterio: cuando sea tu alma de las Desilusiones el imperio; cuando el sufrir tus lágrimas agote; cuando inmisericorde su cauterio 
te aplique el Mundo, y el dolor te azote, puedes salvar la puerta tentadora, la puerta blanca, la Thulé postrera; entonces - dije- es hora.

$\mathrm{Y}$ entré con paso firme y alma entera.

Quedé atónito. Hallábame en un campo de nieve, de impoluta perspectiva: cada llanura, un ampo; cada montaña, un irisado bloque; cada picacho, una blancura viva. Y de la luz al toque eran los farallones albicantes chorreras de diamantes.

- ¿En dónde estoy?- me dije trémulamente; y un soplo de dulzuras teologales trajo a mi oído regalado acento:

-Estás lejos de aquellos arenales ardientes, donde surgen tus pasiones $y$ te devoran como cien chacales. Lejos de las extrañas agresiones;

a estas cimas no alcanza ni el ojo inquiridor de la asechanza, ni el florido puñal de las traiciones.

Son ignorado asilo al tigre humano y a la humana hiena, a los pérfidos cantos de sirena y al aleve llorar del cocodrilo.

Llegas a tierra incógnita;

a tierra de simbólicas alburas, todo misterio y calma.

Estás en las serenas, en las puras e ignoradas regiones de tu alma. $\mathrm{Y}$ me quedé mirando las alturas.

Helena Ospina Garcés (Colombia, 1944). Poeta, educadora y promotora cultural, es miembro correspondiente de la Academia Dominicana de la Lengua. En su lírica fluye el fulgor del verbo sagrado con clara conciencia religiosa. Católica militante, la poeta colombiana amasa su verbo amartelado en la fragua de lo divino mismo. En tal virtud, verbaliza en la imagen poética un lenguaje impregnado de intuiciones y reflexiones trascendentes. Poseída por la llama de la espiritualidad mística, escribe 
a la luz del Evangelio con la pasión de quien vive lo divino mismo. Las lamentaciones, al modo de Jeremías, son un testimonio que desde los tiempos antiguos, según consta en el Libro Sagrado, alienta el quehacer poético de quien experimenta el "dolorido sentir", que la poeta recrea al revivir en su imaginación el drama de la pasión de Cristo (13):

La vida sin Ti ha perdido

el encanto para mí.

Yo solo morir deseo.

¡Ay! Ahora veo que uno de los malvados que quiebran las piernas de los ajusticiados, se dirige a ti, Hijo. ¡Dirige su lanza directamente a tu corazón, Hijo! ¡Ay! Mis ojos ven nuevo y terrible espectáculo.

Herido tu costado derramó al punto sangre y agua sin mezclarse. Es éste ciertamente prodigio que estremece. ¡Mirad la sangre

del cadáver traspasado! ¡Ved cómo mana agua del costado! ¡Ay, cómo manan, sin mezclarse, sangre y agua del costado! ¡Fluyen sangre y agua del costado! Mana doble fuente de ese lado. Y quien le hirió grita asustado:

¡Verdaderamente era éste, el Hijo de Dios!

Jorge Carrera Andrade (Ecuador, 1902-1978). Desde la visión estética del paisaje, el poeta se adentra en el sentido de lo humano con implicaciones socioculturales. Lírico y simbólico, procura desembarazarse de la angustia existencial por lo que acude a la poesía como fuente de liberación. Autor de varios poemarios, desde El estanque inefable hasta Misterios naturales, que revelan la tesitura de una mentalidad metafísica con sentido cósmico. En "El hombre del Ecuador bajo la torre Eiffel", como un profeta bíblico de nuestro tiempo, este poeta ecuatoriano canta 
el asombro que le producen los adelantos modernos en una urbe cosmopolita. En "Biografía para uso de los pájaros" canta el impacto que las manifestaciones naturales y culturales ejercen en la sensibilidad y la conciencia. En "Nada nos pertenece" (14), evoca el sentimiento del carpe diem, que sugiere la torpe vanidad humana, según canta el Eclesiastés, para concitar una honda reflexión sobre el sentido de la vida y el discurrir del mundo:

Cada día el mismo árbol rodeado de su verde familia rumorosa.

Cada día el latir de un tiempo niño que el péndulo mece en la sombra.

El río da sin prisa su naipe transparente.

El silencio camina a un inminente ruido.

Con sus deditos tiernos

la semilla desgarra sus pañales de lino.

Nadie sabe por qué existen los pájaros; ni tu tonel de vino, luna llena;

ni la amapola que se quema viva;

ni la mujer del arpa, dichosa prisionera.

$Y$ hay que vestirse de agua, de dóciles tejidos, de cosas invisibles y cordiales, y afeitarse con leves despojos de palomas, de arco iris y de ángeles.

Y lavar el escaso oro del día, contando sus pepitas, cuando el Poniente herido quema todas sus naves y se acerca la noche capitaneando sus oscuras tribus.

Entonces habla, Cielo.

Tu alta ciudad nocturna se ilumina; tu muchedumbre con antorchas pasa $y$ en silencio nos mira.

Todas las formas vanas y terrestres: el joven que cultiva una estatua en su lecho, la mujer con sus dos corazones de pájaro, la muerte clandestina disfrazada de insecto.

Cubres toda la tierra, hombre muerto, caído como una rota jaula 


\begin{abstract}
o cascarón quebrado
o vivienda de cal de una monstruosa araña.

Los muertos son los monjes de la Orden de los anacoretas subterráneos. ¿La muerte es la pobreza suma o el reino original reconquistado?

Hombre nutrido de años y cuerpos de mujeres, cuando Dios te espolea te arrodillas,

y solo la memoria de las cosas

pone un calor ya inútil en tus manos vacías.
\end{abstract}

Marco Martos (Perú, 1942). Profesor, promotor cultural y poeta oriundo de la legendaria Piura, posee un fecundo aliento poético y una profunda erudición de humanismo y trascendencia. Dirige la Academia Peruana de la Lengua y ha publicado numerosos poemarios impregnados de la sabiduría espiritual de la más pura religiosidad y la mística cristiana. Cultor de la tradición poética de la gran literatura de raigambre hispánica, con fray Luis de León y san Juan de la Cruz a la cabeza, este cultor de la palabra atiza el motivo que enciende su conciencia espiritual y estética. En "El umbral del Paraíso" (15), despliega el caudal de sus conocimientos bíblicos en un soneto escrito bajo la onda de la espiritualidad cristiana y la estela de la imaginería poética:

El rey David tenía mucho frío.

Estaba lastimado por los años. Conocía de cerca los engaños del poder, de la vida y su hastío.

No entraba en calor con la frazada que le alcanzaba gente diligente; arrugas dibujadas en su frente anunciaban la muerte apresurada.

Con sus senos radiantes y turgentes, la hermosa sulamita fue llevada virgen al tálamo nupcial. Fue amada

con desesperación. Quedó en las mientes de quien llegó al umbral del paraíso.

David por Abisag Ilora. La quiso. 
Gabriela Mistral (Chile, 1889-1954). La obra de esta ilustre poeta chilena ha iluminado la conciencia espiritual de América con la enjundiosa lírica de su inspiración poética. La creación poética de esta poeta originaria del valle del Elqui, que le granjeó el premio Nobel de Literatura, reveló una edificante visión estética y espiritual del mundo. La poeta chilena supo moverse entre las apelaciones concitadas por su caudalosa sensibilidad y el influjo de los grandes paradigmas de la condición humana, como san Francisco de Asís y Rabindranath Tagore. Entre sus lecturas forjadoras figuran como textos insoslayables la Biblia y los clásicos griegos y españoles. Supo tallar las imágenes que su intuición profunda articulaba a la metáfora o al símbolo con un concepto afín a su inclinación religiosa bajo la huella mística de inspiración bíblica. Al valor literario de su creación le endosaba la gema interior de resonancia cósmica. En efecto, la ilustre chilena parecía vivir en contacto con las fuerzas preternaturales de la cantera infinita. En "Libro mío" (16) recrea la huella espiritual que en su mente sembrara la obra inmortal de la Biblia:

Libro mío, libro en cualquier tiempo

y en cualquier hora,

bueno y amigo para mi corazón, fuerte, poderoso compañero.

Tú me has enseñado la inmensa belleza y el sencillo candor,

la verdad terrible y sencilla en breves cantos.

Mis mejores amigos no han sido gentes de mis tiempos; han sido los que tú me diste:

David, Rut, Job, Raquel y María.

Con los míos éstos son mis gentes, los que rondan en mi corazón y en mis oraciones, los que me ayudan a amar y a bien padecer.

Andando los tiempos vinisteis a mí, y yo, negando las épocas soy con vosotros, voy entre vosotros,

soy vuestra como uno de los que labraron, padecieron y vivieron vuestro tiempo y vuestra luz. ¿Cuántas veces me habéis confortado?

Tantas como he estado con la cara en la tierra. ¿Cuándo acudí a ti en vano, libro de los hombres, único libro de los hombres? 
Por David amé el canto,

merecedor de la amargura humana.

En Eclesiastés hallé mi viejo gemido

de la vanidad de la vida,

y tan mío ha llegado a ser vuestro acento

que ya ni sé cuándo digo mi queja

y cuándo repito solamente la de vuestros dolores.

Nunca me fatigaste, como los poemas de los hombres.

Siempre eres fresco, recién conocido, como la hierba de julio,

y tu sinceridad es la única en que no hallo peligro,

mancha disimulada de mentiras.

Tu desnudez asusta a los hipócritas

y tu pureza es odiosa a los libertinos.

Yo te amo todo,

desde el nardo de la parábola

hasta el adjetivo crudo de los Números.

Oscar Cerruto (Bolivia, 1912- 1981). Poeta y novelista boliviano representante de la vanguardia hispanoamericana. Diplomático y periodista, fue miembro de la Academia Boliviana de la Lengua. En "Pequeña balada en la muerte de mi hermana" (17) el poeta boliviano canta una elegía inspirado en el tono de lamentación del texto bíblico:

¡Eras tan niña, hermana, para un viaje tan largo!...

II

Lejos de tu suave muerte, no pude verte partir.

Pero te imagino distraída, intacta en la costumbre

de alterar la oscuridad del duelo

encendiendo una sonrisa.

$\mathrm{Y}$ te veo alejarte con paso cauteloso

por la calle del cielo

como para asomarte a la ventana.

Aletearía el júbilo en tus pestañas,

cuando echaste a correr

por los campos de estrellas;

quizá sí te olvidaste de nosotros

en el primer momento.

¡Qué voz nueva, qué aire limpio,

qué resonancias caras en tu sueño!

III 
Pero ¡después has debido sentirte tan sola junto a los ángeles tranquilos!...

IV

Corre el agua clara de las escrituras, y con manos de vírgenes pulsan la lluvia de las liras; y el coro de los querubines pasa sobre el lomo de las nubes "albo vellón de sacrificios" lo mismo que en las páginas de tu Historia Sagrada.

Tú estarás cultivando rosas místicas mientras suben, dulcemente, las campanas de la tierra.

Y me verás perdido, en la hojarasca de los días, por las plazas del mundo, lejano.

E inútilmente gritarás mi nombre y agitarás la mano. ¡Qué tristeza la tuya en el teatro azul de los milagros! ¡Si solo hay desconocidos a tu lado!

Emilio Oribe (Uruguay, 1893-1975). Médico, profesor y poeta, fue decano de la universidad y miembro de la Academia de Letras del Uruguay. Publicó poemarios y ensayos con el aliento platónico de su visión del mundo, que engarza a su concepción metafísica de la existencia y al trasfondo bíblico de su creación poética, cuya hondura formaliza en densas imágenes impregnadas de aroma antiguo y del bello decir profundo y trascendente. Inspirado en las estéticas simbolista, ultraísta y trascendentalista, la fuerza de su lírica y el aliento de su intuición reflejan la onda mística de su estro poético. Como acontece en los buenos creadores, a veces una palabra, un eco o un personaje de la historia son suficientes indicios del lenguaje bíblico, como lo evidencia el poema "Las liras de la lámpara" (18), del poeta uruguayo que hemos elegido para representar a su país en esta muestra de la poesía inspirada en la Biblia:

La noche es rito o drama y hay un fulgor oculto en cada hoja,

Solo una luz me llama;

del pensar me despoja, con su distante ciudadela roja.

Es la lámpara viva, la que el andar del solitario alumbra, 
la plenitud cautiva,

la que adorna y deslumbra, desde un jardín de universal penumbra.

La lámpara sin velo, la gran ave de púrpura que ampara

la beatitud del cielo

en la aurora, y depara pluma de luz más que los astros clara.

La lámpara infinita que es unidad. El ascua milenaria

cuya forma vi escrita, para siempre, en la varia materia de los astros, estatuaria.

La lámpara del canto; la lámpara del ojo del salmista, cuyo óleo es el llanto;

la lámpara imprevista que se enciende y se extingue en el artista.

Yo esa lámpara aspiro más que todas. La lumbre que me manda su cárcel de zafiro.

La lámpara que anda y que un amor sin pausa me demanda.

La lámpara que anda; la lámpara infinita que no pesa. ¿La luz que un Dios me manda? ¿La luz con que El me besa? ¡Ya no adoro más lámpara que esa!

Hugo Rodríguez-Alcalá (Paraguay, 1918-2007). Ensayista, poeta, narrador y crítico literario. Doctor en Filosofía y Letras por la Universidad de Wisconsin, fue director de la Academia Paraguaya de la Lengua Española, Premio Nacional de Literatura y orientador literario. Su ilustre compatriota, Augusto Roa Bastos, escribió del poeta: "Mezcla de canto épico y lírico, el poeta-combatiente había logrado transcribir en aquellos poemas secos y ardientes la terrible pesadilla; una rapsodia espectral, despojada de todo lo que no fuera su propia incandescencia, que revivía el trágico vía crucis de dos pueblos sobre el "vértigo horizontal" de ese 
Gólgota del infinito y plano desierto chaqueño con su decoración de espinas, reverberaciones y alucinaciones, en medio de ese laberinto e infierno de "rectas" y cañadones, a un tiempo solar y nocturno, donde la sed -la muerte blanca- paría a sus hijos y los devoraba rumiando con deleite esa porción de fugaz eternidad que es la vida de un hombre" (19). En su poemario Palabras de los días, reflejo de su búsqueda de lo esencial en la sensorialidad de lo viviente, expresión de lo que los antiguos hebreos atribuían a las crónicas de la Biblia, el poeta recrea el caudal de sus vivencias a la luz de las cosas que pasan, como podemos constatar en "La parra y la higuera”, título simbólico del repertorio bíblico, confirmado por el epígrafe de 1 Reyes 5, 25: “...vivían sin zozobra ninguna, cada cual a la sombra de su parra o de su higuera...", en grata alusión a la apacible vida y al paraíso soñado, que describe en pareados versos antitéticos:

Iba de calle a calle la casona y su parra cubría los dos patios.

¡No pediría hoy más que su techumbre de pámpanos; el brillo de sus uvas

que asedian las abejas; la luz mágica del sol, tenaz, buscando entre las hojas

la núbil golosina que en noviembre madura poco a poco en miel caliente!

Al final de la parra está el aljibe $y$, dentro de él, un circulo celeste copia el vuelo fugaz de las palomas. ¡Ir del aljibe al corredor lejano:

arriba, los sarmientos y racimos; a ambos lados, higueras y rosales,

$y$, en el aire, el silencio y la canícula, el duende de las siestas, la cigarra!

Si no está el Paraíso en el futuro, en el pasado está, perdido a medias: 
mi infancia vivirá mientras yo viva y habrá sobre ella una encendida parra:

lejano cielo verde sobre el mundo.

II

La otra noche soñé con ella: estaba silenciosa la casa como siempre.

Yo miré sus tejados desde arriba porque el sueño era un sueño y yo era pájaro.

Casi negras las tejas, y musgoso el antepecho del aljibe blanco.

La parra no existía: unos sarmientos oscuros se morían de tristeza

cobre el gran esqueleto ennegrecido que era antaño telar de su verdura.

Descendí hasta el brocal, miré hacia adentro: sólo hallé oscuridad y telarañas.

Lancé un grito esperando antiguos ecos, pero siguió el aljibe ciego y mudo.

Volví a mi hoy, y entonces como antaño, lejanamente vi la parra verde,

sus maduros racimos y su sombra.

Y deseché los sueños, no el recuerdo.

Jorge Luis Borges (Argentina, 1899-1986). Reveló el afamado escritor argentino que el recuerdo de su madre leyéndole la Biblia es uno de los caminos para comprender el origen de su carrera literaria. En mi obra La mística en América, consigné sobre el escritor argentino: "Experimentó la desdicha, pero la sublimó, transmutando la dolorosa experiencia en sustancia de su arte. Desde el 'punto transfinito' en donde se encuentre, desde El Aleph de su morada eterna, es decir, desde "el lugar donde están sin confundirse, todos los lugares del orbe”, el hacedor de ficciones logró ciertas imágenes eternas, a pesar de haber reiterado que esas imágenes no lo salvarían porque "lo bueno no es de nadie, ni 
siquiera del otro, sino del lenguaje y la tradición". En su estudio sobre "La Cábala", Borges habla de una de las leyendas más reveladoras de esa doctrina mística, la del Golem, concepto que le inspiró un poema y dijo: "Dios toma un terrón de tierra (Adán quiere decir tierra roja), le insufla vida y crea a Adán, que para los cabalistas sería el primer Golem. Ha sido creado por la palabra divina, por un soplo de vida; y como en la cábala se dice que el nombre de Dios es todo el Pentateuco, salvo que están barajadas las letras, así, si alguien poseyere el nombre de Dios o si alguien llegara al Tetragrámaton -el nombre de cuatro letras de Diosy supiera pronunciarlo correctamente, podría crear un mundo y podría crear un Golem también, un hombre" (20). Su poema “Juan, I, 14" revela su visión mística del mundo:

No será menos un enigma esta hoja que las de mis libros sagrados ni aquellas otras que repiten las bocas ignorantes, creyéndolas de un hombre, no espejos oscuros del Espíritu.

Yo que soy el Es, el Fue y el Será, vuelvo a condescender al lenguaje, que es tiempo sucesivo y emblema.

Quien juega con un niño juega con algo cercano y misterioso;

yo quise jugar con mis hijos.

Estuve entre ellos con asombro y ternura.

Por obra de una magia

nací curiosamente de un vientre.

Viví, hechizado, encarcelado en un cuerpo

y en la humildad de un alma.

Conocí la memoria,

esa moneda que no es nunca la misma.

Conocí la esperanza y el temor, esos dos rostros del incierto futuro.

Conocí la vigilia, el sueño, los sueños,

la ignorancia, la carne,

los torpes laberintos de la razón,

la amistad de los hombres,

la misteriosa devoción de los perros.

Fui amado, comprendido, alabado y pendí de una cruz.

Bebí la copa hasta las heces.

Vi por mis ojos lo que nunca había visto: 
la noche y sus estrellas.

Conocí lo pulido, lo arenoso, los desparejo, lo áspero,

el sabor de la miel y de la manzana,

el agua en la garganta de la sed,

el peso de un metal en la palma,

la voz humana, el rumor de unos pasos sobre la hierba,

el olor de la lluvia en Galilea,

el alto grito de los pájaros.

Conocí también la amargura.

He encomendado esta criatura a un hombre cualquiera;

no será nunca lo que quiero decir,

no dejará de ser su reflejo.

Desde Mi eternidad caen estos signos.

Que otro, no el que es ahora su amanuense, escriba el poema.

Mañana seré un tigre entre los tigres

y predicaré Mi ley a su selva,

a un gran árbol en Asia.

A veces pienso con nostalgia

en el olor de esa carpintería.

José Lezama Lima (Cuba, 1912-1976). Creador de una poesía fraguada en el reino de la imaginación estética, réplica de la visión paradisíaca de la conciencia trascendente y de la concepción platónica de lo viviente, hace de la palabra un puente hacia el infinito. Ocupa un privilegiado lugar en la poesía metafísica americana, en la cual ha ejercido gran influencia a través de las revistas Verbum y Orígenes. En "San Juan de Patmos ante la Puerta Latina" (21), Lezama Lima aborda la realidad de lo sagrado con el lenguaje de la metafísica y aliento bíblico de la trascendencia:

Su salvación es marina:

su verdad de tierra, de agua y de fuego.

El fuego en la última prueba total;

pero antes, la paz: los engendros de agua y de tierra.

Roma no se rinde con facilidad, ni recibe por el lado del mar:

su prueba es de aceite, el aceite que mastica las verdades.

El aceite hirviendo que muerte con dientes de madera, de blanda madera que se pega al cuerpo, como la noche

al perro, o al ave que cae hacia abajo sin fin.

Roma no se fía y su prueba es de aceite hirviendo,

y sus dientes de madera son la madera

mucho tiempo sumergida en el río, blanda y eterna, 
como la carne, como el ave apretada hasta que ya no respira.

San Pablo ganaría a Roma, pero la verdad es que san Juan de Patmos ganaría también a Roma, ved su marca, su fuego, su ave.

Los ancianos romanos le cortaron la cabellera;

quieren que más nunca la forma sea alcanzada; tampoco el ejemplo de la cabellera y la pleamar de la montaña.

San Juan está fuerte, ha pasado días en el calabozo y la oscuridad engrandece su frente y las formas del Crucificado. Ha gozado tanto en el calabozo como en sus lecciones de Éfeso.

El calabozo no es una terrible lección, sino la contemplación de las formas del Crucificado.

El calabozo y la pérdida de sus cabellos debían de sonarle como un río,

pero él solo es invadido por la ligereza y la gloria del ave.

Cada vez que un hombre salta como la sal de la llama,

cada vez que el aceite hierve para bañar los cuerpos de los que quieren ver las nuevas formas de Crucificado, igloria!

Ante la Puerta Latina quieren bañar a san Juan de Patmos;

su baño no es el del espejo y el pie que se adelanta

para recoger como en una concha la temperatura del agua.

No es su baño el del cuerpo remilgado que vacila entre la tibieza miserable del agua y la fidelidad miserable del espejo.

¡Gloria! El agua se ha convertido en un rumor bienaventurado.

No es que san Juan haya vencido el aceite hirviendo:

ese pensamiento no lo asedia, no lo deshonra.

Se ha amigado con el agua, se ha transfundido

en la amistad omnicomprensiva.

No hay en su rostro el orgullo levísimo, pero sí dice:

"Allí donde me amaste con el aceite hirviendo, id y construid una pequeña iglesia católica".

Esa iglesia es aún hoy, porque se alza sobre el martirio de san Juan:

su prueba, la del aceite hirviendo, martirizada su sangre.

Levantad una iglesia donde el martirio encuentre una forma.

Todos los martirios, la comunión de los santos, todos a una como órgano,

como respiración espesa como el sueño del ave, como el órgano alzando y masticando, acompañando la voz,

el cuerpo divino a un tiempo en la comunión de los Santos.

El martirio, todos los martirios, alzando una verdad sobrehumana:

el Senadoconsulto no puede declarar sobre la divinidad de los dioses.

Solo el martirio, muchos martirios, prueban, como la piedra, hacia sí, hacia el infierno sin fin.

Los romanos no creían en la romanidad.

Creían que combatían sus pequeños dioses, hablando

de la ajena soberbia, y aquel Dios era Uno que excluía,

era el Uno que rechaza la sangre y la sustancia de Roma.

José Luis Vega (Puerto Rico, 1948). Poeta, profesor, académico 
y promotor cultural, es la figura poética más importante en las letras puertorriqueñas. Director de la Academia Puertorriqueña de la Lengua Española y autor de varios poemarios, entre ellos Sínsoras, en su lírica se integran la visión metafísica de lo viviente, la realidad cuántica de la Creación y el aliento poético. Escribe inspirado en sus intuiciones y vivencias. La experiencia cuántica entraña una compenetración física y metafísica con lo existente. Al vivir esa experiencia implica sentir una "experiencia cardinal", de la que hablaba Carl Jung, que José Luis Vega ha experimentado en los momentos mágicos de sus vivencias. Es un estado especial de la conciencia, arrebatada por los efluvios del Cosmos; un estado especial de la sensibilidad, concitada por las señales de las cosas; un estado especial de la inspiración, excitada por las manifestaciones sensoriales y espirituales de la realidad. En ese singular estadio de la sensibilidad y la conciencia, fluyen la contemplación, las intuiciones y la creatividad, como se puede inferir de su poema "Elegía a Saulo en dos tiempos", en el que coteja la vida de un amigo boricua con la vida de Pablo de Tarso, a la luz de lo que dice el texto bíblico:

Saulo de Tarso nació en Cilicia, cerca del año 5, después de Jesucristo. Saúl Ramos nació veinte siglos después en la isla de San Juan de Puerto Rico.

Saulo de Tarso, pese a ser hijo de judíos, era ciudadano romano.

Saúl Ramos, hijo de los alisios, fue ciudadano norteamericano.

En sus años mozos, Saulo de Tarso hizo cosas de las cuales se arrepintió después. Saúl Ramos también.

Saulo de Tarso fue un rico fariseo que un día, camino de Damasco, vio a Jesús.

Saúl Ramos, parado ente un semáforo, camino de su empleo, vio otra luz.

Saulo de Tarso decía que la carne es una cosa y el espíritu otra. Saúl Ramos sospechaba que ambos son la misma cosa.

Saulo de Tarso, también llamado Pablo, recorrió medio mundo predicando una nueva religión.

Saúl Ramos, quien no tuvo más nombre que el suyo, cada sábado de Dios jugaba al golf. 
Con los retazos de su vida, Saulo de Tarso escribió siete epístolas que hoy se conservan en la Biblia.

Con los retazos de la suya, Saúl Ramos halló el humor de la sabiduría.

Saulo de Tarso les dijo a los corintios: "mejor es casarse que abrasarse". Saúl Ramos se abrazó a mucha gente hasta cansarse.

Cuando Saulo de Tarso murió decapitado en Roma, una fuente brotó. Saúl Ramos murió crucificado por el cáncer en un hospital de Bayamón.

Según las escrituras, Saulo de Tarso vive en la Nueva Jerusalén. Según este poema, Saúl Ramos también.

Katia San Millán (Haití, 1956?). Pintora y poeta haitiana con una visión interiorista de la vida y del influjo de la divinidad en la conciencia. En una genuina expresión de una experiencia cardinal, la poeta interiorista logra un cauce abierto, intenso y caudaloso del estado emocional y espiritual que experimenta al sentir la huella de lo viviente en su contacto con los elementos con los que se siente integrada o compenetrada en el fluir de sus efluvios físicos y metafísicos. Estremecida por la fuerza del mundo, su poema parece una revelación mística a la luz del misterio del Universo o de la Energía Espiritual del Cosmos. Poseída por el alma del mundo, entra en conexión metafísica con el poder subyacente de fenómenos y cosas. El poema que elegimos como muestra es fruto de una luminosa inspiración. Sin duda fluye en su composición la intuición de una mente sutil y el arrebato de una emoción estremecida, factores desencadenantes de la emoción estética, que se manifiesta en su creación impregnada del aliento bíblico de la Tríada de la Esencia infinita, del pacto entre el Cielo y la Tierra, de la auto-percepción como polvo y soplo en su tránsito terrestre. El poema canta, con el lenguaje de la lírica moderna, el sentimiento de la vinculación de todo con el Todo, convicción mística que ya los antiguos pensadores presocráticos habían intuido y que la mística cristiana asume y recrea con alto sentido espiritual. Se trata, en suma, de palpar la materia, vivirla y sentirla en todos sus aspectos, entendiendo que el Espíritu está en todo, para que las cosas tengan un sentido. Palpar la materia conlleva ahondar en el trasfondo de sus fluidos 
para sentir la voz de la tierra, el eco del aire, el aliento de la lluvia y los efluvios de los astros, la luna y las estrellas, que impactan la sensibilidad y la conciencia. El vínculo con la Energía Espiritual del Universo, que establecemos desde el centro de nuestra sensibilidad como índice y expresión de nuestra dimensión espiritual, fecunda la vertiente metafísica de la creación. Sorprende ese vínculo con la Fuerza del Universo que atraviesa la expresión de la poeta desde la onda espiritual de su sensibilidad profunda con un atisbo hondo y sutil de su inteligencia intuitiva, como se vislumbra en "Nexos" (23):

Soy hija bastarda de la luna y del sol.

Fruto de un eclipse total de sol, del acoplamiento de la luz y la sombra.

Cada una perfecta, cada una única. De un encuentro pasión, de un encuentro ternura.

Celebración cósmica de armonía pura.

Soy el resultado mágico del momento sagrado

en que los números, precisos, lógicos, en un acceso de locura hicieron que uno más uno sumaran tres.

Y desde entonces, llevo impresa en mí el anhelo eterno del tres en Uno. Soy hija del día, hija de la noche y para no vagar como niña perdida entre polvo de estrellas, la Tierra me acogió tierna y amante, me nutrió y me cobijó.

Por eso la llamo Madre.

$\mathrm{Y}$ desde entonces soy mineral, vegetal, animal y humana.

En mi piel mestiza soy barro, soy polvo.

En mi pelo bastardo soy musgo, soy liana.

En mis venas recias soy sangre, soy savia

y hago mi cama en el humus blando y fecundo y lanzo raíces profundas hasta el mismo centro del Universo.

$Y$ hago brotar retoños tiernos, y multiplico hojas y ramas

y me hago flor y me hago fruta y celebro el árbol altivo e imponente que también soy yo, que desdibuja la frontera entre lo limitado y lo infinito.

Que es puente entre la realidad y el misterio.

Esto me lo susurró la voz de los ancestros

Que llegó cabalgando sobre el viento, mientras él jadeaba de alegría entre la hierba mojada en los campos, mientras suspiraba en la soledad de la sabana, mientras aullaba en la tristeza del desierto, mientras chismeaba entre los arrozales, mientras rugía y escupía su ira 
entre las ráfagas mortales de los relámpagos,

mientras se hacía murmullo

tierno y suave en la brisa del alba.

Mientras invisible pero presente

fecundándolo todo, fecundaba mis pensamientos.

Ese viento que también soy yo.

$Y$ también soy fuego.

Tengo mis raíces en el mismo sol.

Y cada intento mío de manifestarme

me lleva hacia arriba, siempre arriba

lamiendo el aire con miles de lenguas verticales y temblorosas,

Siempre aspirando al reencuentro con mi linaje real, estremecido por mi propia belleza.

Soy lava dorada hecha luz, translúcida, diáfana, frágil, dadora de caricias cálidas y tiernas.

También soy mordisco ardiente que insufla pasión y brío.

En el atanor de los alquimistas, en el secreto del misterio

celebro el negro, el rojo, por fin el blanco,

limpiando, calcinando, purificando, dejando

como pruebas irrefutables de la gran transmutación,

Las cenizas todavía humeantes, abono imprescindible y vital,

materia prima del próximo nivel.

Y me muevo pero con frescura, húmeda y azul.

Transparente y líquida, fluida e inasible

en variaciones ondulantes, inventando olas,

volviéndome marea o espejo.

Y a mi antojo escupo la espuma

o me dejo tragar por la arena golosa, me deslizo sensual y atrevida

sobre los peñascos afilados del rechazo

lamiéndolos incasablemente

hasta volverlos guijarros pulidos y juguetones

con la promesa de surcar mi superficie

en miles de anillos concéntricos.

Me dejo alborotar por el viento insolente,

apago el fuego del deseo o fecundo la tierra sedienta.

Esa soy yo el agua, cerrando la cuadratura perfecta de la materia.

$Y$ para celebrarme entera, renuevo el pacto del encuentro

primero entre el Cielo y la Tierra.

Dibujo un arco iris-puente, me deslizo sobre sus colores hechos luz

y alcanzo la esfera de mi alma.

La siempre presente, la que espera sedienta pero paciente

que yo vuelva a la raíz, que yo recuerde el origen,

que mi hambre de Luz sea mayor

que mi apetito por los destellos de la ilusión.

que la Voz del que planeaba

sobre la superficie del agua primigenia

sea más fuerte que los cantos de sirenas.

Esa, mensajera del Innombrable en la Tierra, 
esa la que crece o desfallece.

La que vive o muere, esa, enlace perfecto, engranaje imprescindible en la Tríada que forma mi Esencia, esa que hace posible

El cuatro más siete que no es más que Uno.

Esa que espera el beso último, el abrazo consentido, infinito e imborrable de la Nada que no es más que el Todo.

Máximo Avilés Blonda (República Dominicana, 1930-1996). Este poeta dominicano escribía bajo la fecundación del aire con sus diversas modalidades de concreción: soplo, aliento, voz, canto y halo, que vincula a la Energía Espiritual del Universo y, por supuesto, al Espíritu Santo, según ha consignado el Libro sagrado. En efecto, el poeta asume el aire como la sustancia vital de su creación y, desde su sensibilidad empática, observa la realidad que concita su aliento creador. Ya sabemos que la voz, como el aire o la luz, es puente para acceder a la realidad trascendente, según consigné en mi obra La lírica metafísica. $Y$ en tal virtud, nuestro poeta canaliza los efluvios que proceden, con su connotación metafísica, religiosa y mística, de la copiosa cantera infinita. La voz, soplo sensorialmente perceptible en su peculiar condición vaporosa, es canal de lo intangible. Por eso los antiguos profetas oían una voz, un susurro, un soplo diciente con la extraña sensación de lo inefable. Y acataban la revelación del más allá con singular veneración. En "Jeremías" (24), alter ego del poeta a través del cual el creador proyecta su palabra, cada uno de los personajes bíblicos de Los profetas, el singular poemario de Máximo Avilés Blonda, la voz lírica es una vía para cantar alabanzas al Creador del Mundo, como lo han sentido los contemplativos de las diversas culturas:

Alborozaos, cabezas;

vengan cantos de júbilo en gargantas; alabad y anunciad la promesa del Uno en la Zarza,

la Promesa de quien dice Yo Soy.

Se hace el todo que respira,

se hace justicia después de la ley fuerte, se hace pura equidad después de la Gran Norma, después de pequeños reglamentos y preceptos pequeños, se hace todo más grande con el crecer de tierras, con el crecer del amor, del sacrificio, 
los granos para muchos, el florido sarmiento y la ternura, se hace más grande con las grandes crecidas de los ríos...

Se hace grande la alabanza y el misterio.

Queda pequeña entre las piedras la maldición pequeña. Por eso digo, yo, llamado desde el agua creciente:

¿Hasta cuándo correr por los caminos, por el viento y el páramo, por la estepa fría, si he sido signado por el fuego?

(Suave es el Señor cuando es sueño de aguardo)

Nada lejano hay, nada remoto...

Y hoy, soy cántaro roto de palabra, vasija vidriada, estrellada

a las puertas del valle, con fuerza, obra de manos alfareras,

venidas después del agua tibia, agua terciada en el vientre de la dicha, agua quebrantada en el amor, agua sacada por torpes manos por el lamentarse de la voz del barro ya crecido, por la prisa del barro en convertirse en estrella.

Espero aquí sentado desde entonces, me lamento a veces, por el tiempo, bajo el polvo del dintel, junto a la sombra de los batientes, con el menguar y el crecer de lunas, la anunciada gloria de los cuerpos.

Estas cosas fueron señaladas aquí, mi lengua que escribe

¡Oh, mi Baruc, tú, mi mano que piensa, tú, el trazo de mis labios en el rollo que es la voluntad del Grande, amado Baruc, compañero, hermano,

hijo o casi yo mismo, zapato de mi pie, apoyatura mía, muleta, mi brío, mi resistencia!

¡Toma un codo de la medida de la Gracia y déjalo como espejo claro a la tierra que amamos o repártelo como agua entre los hombres!

Sintetizo el influjo bíblico en la poesía americana: 1 . Huella del decir bíblico a través de los recursos literarios empleados en el Libro Sagrado. 2. Reminiscencias de temas, personajes y motivos inspirados en paradigmas bíblicos. 3. Empleo de imágenes, técnicas y el tono bíblico, canalizados de manera lírica, estética y simbólica.

La vivencia de la sacralidad religiosa y mística a la luz de la creación poética de inspiración bíblica tiene una ejemplar realización en el cultivo 
de las letras americanas. De ahí el impacto literario de una obra como la Biblia en el pensamiento religioso, la cultura mística y la creación de nuestros poetas, que se manifiesta en la cosmovisión espiritual y en el arte que subyuga la inteligencia y cautiva la sensibilidad para deleite de la emoción estética y gozo de la fruición interior.

\author{
Bruno Rosario Candelier \\ $\checkmark$ Coloquio de Teología y Literatura \\ Santiago de Chile, 2 de octubre de 2014.
}

\title{
Notas:
}

1. Cfr. Pseudo Dionisio Areopagita, Obras completas, Madrid, BAC, 1995, pp. 128 y 148.

2. El texto en inglés, que citamos en la traducción de Google, es el siguiente: "Red apples and brown coffee/ in the indigo dawn early/paired, dark forms of ducks/ moving in water,/ seem like strange rocks/ or the breasts of my daughter/ as the motorway develops/ images of autos and truck stops./ a motel sign glares blood-red,/ opposite a home of the freshly-dead./ the black body of a Bible,/ lynched on the tree of a table,/is motionless as possible. If would read it if i were able/ (if its words were not birds of prey/ in a bombersky, olive and grey)./ coin-operated lovers/ exchange lucre in cold covers./ piercing lights of Moloch lamps/ hurl arrows of electricity/ to drive out darkness where it camps/ in the stock markets of the city./ I would alter if there was change/ to alter what is not prearranged. / I have lost so much of what was nothing/ (even the stars above the lakes are frothing)./ Have i said that my daughter's breasts/ are like two, young, black swans?/ that each generation of emptiness rests/ upon my toiling for such futile funds?/ going forth mornings to keep alive/ the human doom, the "twoo-human drive. . .".

3. Fray Paul Dupuis (Pablo de Jesús) nació en Nueva Inglaterra, Estados Unidos de Norteamérica, en 1942. Sacerdote, educador y poeta místico, reside en Boston. Cultiva la poesía mística, que alterna con su tarea profesional y espiritual. Profesor de Teología y Espiritualidad en la Universidad de Harvard, donde se doctoró en Filosofía y Letras. Vive místicamente el mundo, fincado en el estudio, la docencia y la creatividad. Abrazó el Interiorismo, cuya tendencia estética cultiva en sus poemas, paradigmas de belleza y sentido. Cfr. Bruno Rosario Candelier, La creación interiorista, Moca, Ateneo Insular, 2001, p. 269. Fernando Beltrán Llavador, "Thomas Merton y la identidad del hombre nuevo", en Luce López-Baralt y Lorenzo Piera Delgado, El Sol a medianoche: La experiencia mística, tradición y actualidad, Madrid, Trotta, 1996, p.126. Además, Bruno Rosario Candelier, "La creación teopoética en la lírica de fray Paul Dupuis", en La mística en América, Santo Domingo, Ateneo Insular, 2010, pp. 75-90.

4. Amado Nervo desarrolló una intensa carrera literaria en el Correo de la tarde, diario de Mazatlán, y en la revista Azul. Publicó Perlas negras, Lira heroica, El éxodo y las flores del camino, Las voces, Los jardines interiores, Serenidad, Elevación, El arquero divino, entre otros libros. Cfr. Julio Caillet Bois, Antología de la poesía hispanoamericana, Madrid, Aguilar, 1965, p. 766. 
5. Gustavo González Villanueva, sacerdote y poeta guatemalteco, nació en Antigua, Guatemala, donde reside y hace vida religiosa, académica y cultural. Doctor en Teología por la Universidad Lateranense de Roma, fue profesor de la Universidad de Costa Rica y es miembro correspondiente de la Academia Dominicana de la Lengua. Ha publicado varios libros de poesía, ensayo y novela. Ver Gustavo González Villanueva, Poema del sueño y del viaje de la mamá buena, San José de Costa Rica, Promesa, 2007, pp. 4244. Cfr. Bruno Rosario Candelier, "La onda sublime en la lírica de Gustavo González Villanueva”, en La mística en América, citado, pp. 165-185.

6. Julieta Dobles, Costa Rica Poema a Poema: un recorrido por el alma secreta de la patria, San José de Costa Rica, Editorial EUNED, 1997, pp. 165-167.

7. En Anthony J. Robb, La poética de Conny Palacios, Pavsa, 2004, p. 138. Conny Palacios nació en Matagalpa, Nicaragua, en 1953. Hizo sus estudios graduados en la Universidad de Miami, Florida. En Saint Thomas obtuvo el doctorado en Literatura Hispanoamericana. Miembro correspondiente de la Academia Nicaragüense de la Lengua, ha participado en congresos literarios en diferentes países y escrito artículos y poemas en revistas especializadas y antologías. Ha publicado las novelas En carne viva (1994) y Silarsuami (2011); el ensayo Pluralidad de máscaras en la lírica de Pablo Antonio Cuadra (1996) y los poemarios Exorcismo del absurdo (1999), Percepción fractal (1999) y Radiografía del silencio (2003), entre otros. Cfr. Bruno Rosario Candelier, "La conexión cósmica en la lírica de Conny Palacios", en La belleza y el sentido, Santo Domingo, Ateneo Insular, 2012, pp. 327-346.

8. Cfr. Fausto Leonardo Henríquez, Los Novísimos, Ed. Guaymuras, 2002, pp. 17 y 22.

9. David Escobar Galindo, prestante cultor de la lírica teopoética en El Salvador, presidió la Academia Salvadoreña de la Lengua y ha escrito varios poemarios centrados en la búsqueda de lo divino.

10. José Guillermo Ros-Zanet, Poesía reunida, Panamá, Academia Panameña de la Lengua, 2004, pp. 183-184. Cfr. Bruno Rosario Candelier, La mística en América, citado, pp. 233- 250.

11. Cecilia Meireles en Gabriela Mistral y Cecilia Meireles, Santiago de Chile, SermografArtes Gráficas, 2003, pp. 143-145.

12. En Julio Caillet Bois, Antología de la poesía hispanoamericana, citado, pp. 876-877.

13. Educadora y catedrática universitaria, la poeta colombiana Helena Ospina Garcés reside en San José de Costa Rica, donde realiza una fecunda labor de promoción literaria bajo el sello editorial Promesa y el auspicio de la Universidad de Costa Rica. Ha publicado numerosos poemarios, como El cantar de cantares, Poiein, Splendor formae, Splendor personae, Splendor gloriae, Cantata a las artes, Eva-María, Divino Artífice, Divina herida, Andadura de vida, Navío de estrella y Sonata de otoño. Cfr. Helena Ospina, Stabat Mater, San José de Costa Rica, Promesa, 1995, p. 35. Cfr. Bruno Rosario Candelier, "La intuición mística en la poesía de Helena Ospina Garces," en La mística en América, pp. 329-340.

14. En Julio Caillet Bois, Antología de la poesía hispanoamericana, citado, p. 1367.

15. Marcos Martos, El mar de las tinieblas, Lima, Perú, Atenea Editores, 1999, p. 170.

16. En Bruno Rosario Candelier, "La vertiente mística en la lírica de Gabriela Mistral”, en La mística en América, citado, pp. 295-310.

17. En Julio Caillet Bois, Antología de la poesía hispanoamericana, p. 1670.

18. Ibídem, pp. 1441-1442. 
19. Hugo Rodríguez-Alcalá, Palabras de los días, Maracaibo, Venezuela, Editorial Universitaria de la Universidad de Zulia, 1972, pp. 8 y 23-25. El poeta, profesor y crítico paraguayo es el autor de Horas líricas, La danza de la muerte, A la sombra del pórtico, Estampas de la guerra y Palabras de los días.

20. En Bruno Rosario Candelier, "La pasión espiritual y estética en Borges", en La mística en América, pp. 315ss. Y Jorge Luis Borges, Páginas escogidas, Casa de las Américas, 1988, pp. 56-57.

21. José Lezama Lima, Poesía completa, La Habana, Editorial Letras Cubanas, 1994, pp. 36-38.

22. Cfr. Bruno Rosario Candelier, La experiencia cuántica en la poesía de José Luis Vega, Santo Domingo, Ateneo Insular, 2014, p. 9. Y José Luis Vega, Sínsoras, México, Seix Barral, 2013, pp. 93-95.

23. Poema inédito, enviado por la poeta interiorista Katia San Millán al autor de este estudio.

24. Máximo Avilés Blonda, Los profetas, Santo Domingo, Editora Profesional, 1978, p. 69. Cfr. Bruno Rosario Candelier, "El aliento numénico en la lírica de Máximo Avilés Blonda", en La lírica metafísica, Santo Domingo, Ateneo Insular, Búho, 2011, p.161.

Bruno Rosario Candelier: Moca, República Dominicana, 1941. Filólogo, profesor, crítico literario, novelista, promotor cultural. Licenciado en educación por la Pontificia Universidad Católica Madre y Maestra, de Santiago de los Caballeros, y doctor en filología hispánica por Universidad Complutense de Madrid. Director de la Academia Dominicana de la Lengua, miembro correspondiente de la Real Academia Española y de las Academias Norteamericana, Puertorriqueña y Filipina de la Lengua Española. Presidente del Ateneo Insular y creador del Movimiento Interiorista. Entre sus libros figuran Lo popular y lo culto en la poesía dominicana, La creación mitopoética, La imaginación insular, Tendencias de la novela dominicana, El sentido de la cultura, El sueño era Cipango, El Interiorismo, El Logos en la conciencia, La mística en América, La lírica metafísica, La belleza y el sentido y La intuición cuántica de la creación. Fue director general de Bellas Artes y editor de "Coloquio", del diario El Siglo. Premio del Instituto de Cultura Hispánica, de Madrid y Premio Nacional de Literatura. 